\title{
The Role of Salesmen's Efficiency in Achieving Effective Marketing Communication with the Buyers' Community- Case Study- "Morouj Commodities Ltd - Sudan"
}

\author{
Saeed Hassan EL-Aageb Hasab El-Karim, PhD, Assistant Professor, \\ Department of Business Administration, College of Administrative Sciences and Humanities, Jouf \\ University.AL, Jouf, Skaka ,Saudi Arabia ,Shendi University \\ Amir Salim Elsheikh Algarrai, PhD, Associate Professor, \\ Department of Administrative Sciences, Community College, Najran University, Saudi Arabia ,P.O.Box 1988, \\ Najran 61441, KSA,Shendi University, Sudan
}

\begin{abstract}
This study aims to identify the role of salesman's efficiency in achieving effective marketing communication with the sales audience (i.e. buyers). The study deals with the problem of some companies that suffer from the weakness of the role played by salesmen in the process of marketing communication and decrease of the size of sales. To achieve the objective of the study, the researchers used the analytical descriptive approach (i.e., questionnaire, interview and observation). The questionnaire covered all aspects of the subject of the study. 70 questionnaires were distributed to the target sample and only (71\%) of the sample was returned (i.e. 50 subjects). The results were then statistically analyzed using, SPSS. The study revealed that Morouj's salesmen have several qualities and skills that contribute to the success of the sales process (i.e., the ability to plan sales and establish good relations with customers and mastering of the art of dealing with customers. Based on these results, the study presented several recommendations; the most important of which are:
\end{abstract}

- The selection of salesmen should be according to specific criteria (efficiency and competency).

- Continuous training, qualification and motivation of sales men.

- The need to achieve satisfaction of the salesmen.

Keywords: Efficient Salesmen, Marketing Communication, Buyers.

DOI: $10.7176 / \mathrm{EJBM} / 11-9-13$

Publication date:March $31^{\text {st }} 2019$

\section{The first topic: the general framework of research 1/ Introduction}

Personal selling is one of the most important elements of the marketing communication mix, which has become very reliable in many private sector organizations in achieving their marketing objectives in general and promotional in particular. However, some organizations still have difficulties in reaching these goals in the required manner because of the low sales efficiency of salesmen, because the success of the sales process depends to a large extent on the qualities and sales skills of the salesman. At present, the importance and role of salesmen in companies engaged in the production and / or marketing of food products is increasing. Since sales are the beginning of a good relationship with the customer, the salesman has to maintain this relationship in the long term to ensure the loyalty of customers towards the products and attracts more customers, and cannot happen only through the availability of certain qualities and sales skills that enable him to find a reputation It is good to maintain existing customers and win new customers. Through the introduction of this subject becomes an important subject in marketing especially in light of the current competition today, which increases the efforts of these organizations in training, motivation and interest

The large salesmen for high competencies are able to achieve effective marketing communication with the buyers' audience. Finally, this study examines the role of salesmen's efficiency in achieving effective marketing communication with the buying public.

\section{2/The importance of the study}

The importance of the study stems from the fact that the subject, is considered a real addition, because of the need of some companies for such research in order to solve the problem of low sales of salesmen because of the low efficiency in the process of marketing communication, many companies relied on them in the process of marketing communications, because they represent the face of the company, where the customer usually sees the company through his dealings with the selling man, this fact prompted the researchers to deal with the subject of research, study and analysis to identify the obstacles that prevent the sales man from doing his work efficiency, so as to achieve the objectives of the company. 


\section{3/Problem of study}

In the current competition between companies, the dependence on salesmen is very important, as the sale begins with the seller, which requires certain qualities and skills which qualify him to become a successful salesman in the performance of his work, some companies suffer from a decline in the volume of sales and the role of salesmen in the process of marketing communication, because of the obstacles that prevent the achievement of their goals set by the company, this causes their low efficiency such as lack of personal qualities and skills that enable them to communicate effectively with customers and ensure success in their work - which are represented in the inability to recognize the reactions of others, speech skills, and all the qualities and skills that enable them to complete the sales transaction - as a result of the lack of education and continuous training.

\section{4/Study hypotheses}

1. There is a statistically significant relationship between the sales efficiency variables of the salesmen education, knowledge, continuous training, skills (planning, communication, conversation), intelligence, explain ability of the commodity in easy language, persuasion, recognize the reactions of others) and decision of buyers.

2. There is a statistically significant relationship between variables of evaluation factors Performance of salesmen (job satisfaction, stimulate, sales skills) and effective communication with the buyers' community.

\section{5/Objectives of the study}

The study aims to:

1. To define the concept of personal selling as a component of the promotional mix and related sub-themes.

2. Know the role of salesmen in the process of marketing communication and the availability of their abilities and skills in creating loyalty to existing customers and attract new customers to ensure the expansion of the customer base of the company.

3. To draw the attention of the officials of the organizations to the importance of selling men and the importance of the effectiveness of their contact with the public of buyers.

4. Detecting communication obstacles between salesmen and customers.

5. Provide salesmen with what is required to develop the relationship with customers.

6. Finding solutions that ensure companies that have salesmen to overcome the low sales efficiency of their sales men.

7. Provide some information to researchers and decision makers in organizations to solve problems related to sales men.

\section{6/Variables of study}

\section{Independent variable}

The independent variable is represented by the salesmen's efficiency and is measured by:

1) Sales efficiency variables for salesmen. Through the following:

(Education, knowledge, continuous training, skills ,planning, Communication, conversation), intelligence, ability to explain in easy language, persuasion, Identify the reactions of others.

2) Variables of the factors of evaluating the performance of salesmen through the following:(Job satisfaction, motivation, sales skills)

\section{Dependent variable:}

In order to achieve effective marketing communication with the buyers' audience, effective marketing communication can be linked to the buyers' audience. The selling man enjoys the qualities and skills of the sales agent, and the majority of the buyers' personal communication effectiveness is characterized by many sales qualities and skills, in addition to other factors such as motivation.

\section{7/Methodology of the study and statistical treatment}

\section{Methodology of the study}

The study adopted the historical methodology in the study of scientific sources and references directly related to the subject of the study, the deductive methodology in studying the problems and hypotheses of the study, and the analytical descriptive methodology in the collection and analysis of data indicators for the field study, which is concerned with collecting detailed data on the phenomena in order to use the data to understand and explain the situations and practices at present, the study has followed the case study methodology, which provides the necessary information and shows the changes required by the comprehensive study, which leads to the discovery of new fields of research and hypotheses for future studies, It also explains the various benefits of statistical results and relates to the various factors and influences that have led to the current results. 


\section{Sources of information collection}

Primary Sources: The data and information obtained from the study community of senior leadership, executive management and supervisors of Morouj Commodities Ltd using the standard study tools (questionnaire, interview, observation.)

Secondary sources: These include sources, references and documents in the field of business administration, especially the department of marketing, promotion, personal sales, sales management and scientific journals, in addition to the university thesis and other studies that proceeded in this area

\section{Study limits}

1) Spatial field: Khartoum State, Chairmanship of Morouj Commodities Ltd .

2) Human field: Employees in the private sector in the field of food products, taking Morouj as a model for the rest of the companies.

\section{Statistical analysis of data}

In order to answer the study questions, the statistical data collected through the SPSS questionnaire were analyzed and the methods used (ratios, frequencies, variance, and square), were used to determine the existence of significant differences between the computation of the sample responses Study towards the role of salesmen in achieving marketing communication.

\section{The second topic: previous studies}

Aisha et al. (2016) conducted a study of the factors affecting the performance of the sales men. A case study at the Samha Foundation (Samsung) Wade Arhiu Agency. Aiming to highlight the effect of selling power management (selection, training, stimulation, control and evaluation) In improving salesmen performance, The problem of research in the question was: What Factors affecting the performance of salesmen in the economic institution?

The study highlighted the importance of identifying the principles that should be applied in performing the functions of sales forces and realizing the role they play in improving the performance of sales men and clarifying the nature of the relationship between the management of sales forces and the development of selling men's performance. The study found that the sales men in the organization have personal qualities that give a positive impression of the capabilities they possess, and also the officials of the institution seek to improve the performance of their salesmen by paying attention to the functions of managing sales forces of training, motivation, supervision and evaluation... The study recommended the need to provide physical incentives to salesmen, and that control and evaluation are the best means to ensure that the work in the right direction

Najah and Nouri (2016) studied the role of training in achieving sales skills development. Case study of the Algerian TextileTEXALGE in Tesmeseleit .The study aimed at clarifying the role of training as it occupies a prominent position among the activities aimed at raising production efficiency and improving the means of work and its methods. The problem lied in the role of salesmen training in the Algerian Textile Establishment. The most important findings were that the performance of the institution is weak, And the most important recommendations are the selection of individuals who possess the qualities that lie mainly in the possession of these men of knowledge, skills and different behaviors, in addition to the possession of competitive capabilities that enable them to achieve creativity and innovation, and all this by training and development of these individuals motivation and others. Fatih and Nadia (2015) conducted a study aimed at highlighting the impact of the personal characteristics of the salesman on his sales performance. A field study on the automotive sector in Algeria. Apart from the rest of the effects or incentives material and moral, was among the findings proved the customer was affected by the physical characteristics of the salesman by studying the impact of appearance and impact on the customer, and the study found that the impact of psychological and behavioral features such as self-confidence, spirit of service and loyalty to the institution have a strong effect I also found that the skill of planning affects the sales man's performance. Mohamed (2013), studied the impact of sales force management on the marketing performance of the institution: the case study of the agricultural enterprise AXIUM-SPA, and the objective of the study to answer the main question: what is the extent of marketing performance of AXIUM Peasant Corporation the study came to the engagement in the conduct of a modern sales force as a way keep pace with new developments in the concept of marketing, highlighting its importance and fundamental cornerstones underlying sales performance. The study of marketing mechanisms to improve their performance. The importance of the study lies in the effective role played by the salesmen in determining the marketing policy of the institution as the final mediator between them and the customer, and their effectiveness to convince them and encourage them to buy. The most important conclusion of the study is that the good performance of the sales force necessarily leads to the improvement and development of the performance of the marketing organization, and the study recommended the institution to pay more attention to the strength of selling, and the objective selection of salesmen and the development of a motivational system to activate the strength of sales in addition to the establishment of scientific and methodological basis of training and stimulate and evaluate the performance of salesmen, Nevin (2010) dealt with the effect of using a salesperson to sell the customer-oriented approach to the short time of purchase. The study aimed at identifying the impact of (showing customer interest, determining customer requirements, customer 
satisfaction, and customer participation in solving problems related to shorten the time of purchase. The problem of the study was to know the effect of the use of customer-oriented sales on the short time of purchase in the small enterprise exhibition. The study examined the effect of the sales representative use of customer-oriented approach to shorten the time of purchase. . The study found a significant effect between (showing customer interest, customer satisfaction, willingness of the sales representative to identify customer requirements, participation of customers in solving their problems and responding to their inquiries) and short purchase time. The study recommended that an included training the sales representatives to pay more attention to the customers and try to discover the methods and behaviors that lead to the customer. To make the sales representatives more interested in their customers, urge salespeople to try to satisfy the customer in the long term and determine what the requirements and needs of the customer and the participation of customers in solving their problems and answer their queries, and in a study conducted by Mahmoud (2003)studied the role of delegate Sales promotion and marketing of cosmetic field study. The objectives of the study were to identify individual differences in the marketing of cosmetics between male and female delegates, as well as to reveal the role of age in marketing the product and the role of the culture of sales representatives in the marketing of cosmetics and the knowledge of the marketing process of companies in creating and finding delegates, who should be available in sales. The problem of the research lied in what skills should the sales men have? What role does he play in marketing? Is there a difference if the salesperson was young man or young woman, and knowledge of the psychological role played by the salesperson? The importance of the study steamed from the importance of the role played by the sales representative, in the marketing of products and the disposal of the large production of the concern. The most important findings were that there were no statistically significant differences in the marketing of products between males and females, and there were no statistically significant differences in product marketing between younger delegates and older delegates. The absence of statistically significant differences in the marketing of products among delegates is attributed to the degree of expertise. The study recommended that a sufficient training period should be established in which the delegate obtains all the information related to the nature of the work and the nature of the products he will be marketing and working to be able to benefit from the expertise of qualified delegates in jobs commensurate with their qualifications. And a recommendation that a psychologist should be appointed so as to carry out its mission to guide delegates towards the best and most successful ways to help market products faster .Marwan (2001) also examined the difficulties faced by the representatives of selling insurance policies in Jordan. The study problem was concerned with the difficulties faced by the representatives of selling insurance documents in Jordan in order to identify ways to reduce these difficulties and ways to overcome them. The research also studied the variables that affect the point of view of sales representatives of insurance policies in the difficulties they face. The study aimed to find the best ways to overcome the difficulties presented by the sales agents. The objective of the study and its importance was to identify the difficulties faced by the sales agents and to know if there was a statistical effect related to sales representatives. Some of the findings were: limited management skills, lack of effective incentive system, inability to deal with different human patterns, and lack of policy to attract customers. Finally, Tarig (1998) conducted a field study of the causes and reasons of failure of sales in industrial companies and the consequences of the failure of sales staff whose objectives were to: Identify the most important indicators and failures in the field of personal selling, know the main reasons for failure in the field of personal sales, Failures in the field of personal selling, how companies deal with this, and knowledge of the consequences of failure in the field of personal sale. The study highlighted the importance of efforts to study the issue of failure of sales staff is few, according to the study of failure in the field of personal sale in directing officials in enterprises to re-rationalize policies for the selection, appointment, reward, stimulation, training and supervision of the personal salesperson, which increases the effectiveness of these policies. The study concluded that: the unethical behavior of the salesman and the decline in the rate of demand of key customers, increase the rate of loss of customers, and targeting customers are inappropriate, and increase customer complaints, and the adoption of bad work habits of the most important indicators of failure to sell from the point of view of the surveyors, including managers and sales staff, sales managers should take responsibility for the failure to sell themselves and blame the capabilities and qualifications of sales team members. The study recommendations were: to ensure that sales managers and sales staff have a common understanding of the meaning and indicators of failure. Managers should assess the importance of both negative and positive outcomes of failure and make informed decisions regarding investment in different areas such as training, stimulate, rehabilitation, selection and placement, and the development of objective criteria for evaluating that performance of sales staff takes into account the experience of the employee and the nature of the task assigned to him, and the development of objective policies declared to deal with sales staff in case of failure of selling. Alsayed and Abdel-Fattah (1989) conducted a study on the behavior of the sales representative between directing the product and directing the customer: A study of the behavior of the sales representative between product orientation and customer orientation: Measuring the perception of vendors and customers in the implementation of the Omer Efendi stores in Greater Cairo. The objectives of the study were to determine the extent to which the sellers' perceptions of their selling behavior differed according to the effect of a group of demographic characteristics. And to determine the extent to which 
customers understand the behavior of selling vendors according to a set of demographic characteristics. Finally, measuring the extent of the difference between the awareness of each of the sellers selling behavior and the awareness of customers to this behavior, to shed light on the degree of perception of the relationship between the seller and the customer, and draws attention to the importance of the seller and his role in the implementation of marketing policies, and also his role in increasing the ability of organizations to adapt to the circumstances and variables of the prevailing marketing environment, in addition to the importance of measuring and identifying the nature of selling behavior from the point of view of the parties to the exchange process (seller and buyer). The study found that sellers are aware of their sales behavior as directed to the customer according to the cognitive scale used. There is no significant effect of the demographic characteristics of the sellers on their understanding of their behavior according to the five factors of know-how. It also found that the customers understand the selling behavior of the sellers as directed to the customer. Sellers of the same behavior for three factors of the study are: show the benefits of the product, honesty in persuasion sales, taking into account the interest of the customer. The most important recommendations were the design of training programs for the sellers to guide their behavior towards the customer's attention to a greater degree. These programs should focus on changing the concepts of the sellers and their attitudes towards the functional and the practice of selling the salesmanship and the skills of dealing with the qualities of the customers and leading to the application of the modern concept of marketing in the field of sales. Emphasis should be placed on providing information and developing skills on aspects where sellers recognized their behavior as product oriented.

\section{The third topic: theoretical framework 1 / marketing Communications}

Definition of marketing communications:

1. Marketing communication is defined as: (Coordination of other promotional and marketing efforts to ensure access to the highest level of information and to create influence and persuasion among customers) (Al-Bakri, 2012: 290):

2. All the instruments [e.g. advertising SP, sponsorship PR, direct marketing, and e-communications] by means of which the company communicates with its target groups and stakeholders to provide its products or the company as a whole. (Finne, Ake; Gronroos, Christian, 2017, p. 447).

\section{2/Personal Selling}

\section{Definition of personal selling}

Personal selling is defined as: (that is, a sales promotion activity involving a salesman's interview with the consumer or the industrial buyer face-to-face with a view to defining the characteristics of the goods or services and persuading them to purchase them) (Idris, 2013: 169)

William Bride defined it as: (the process by which the customer is informed and persuaded to buy a product through a personal contact process between the seller and the buyer where information is exchanged).

"Personal Selling is defined as a process of informing and persuading customers to purchase products through personal communication in an exchange situation" (William M. Bride / O. C. Ferrell, 1983, p162)

"Personal Selling is a person to a person business activity in which a sales person uncovers and satisfies the needs of a buyer to the mutual long term benefit of both parties. "'(Shams al-Din, Basim Abdulrahman, 2011, p10)

"Personal Selling defined as a personal presentation done by sales force in order to build long term relationship and close the sale " (Kakeesh, DanaF, 2010, p15)

"Personal Selling can be defined as two - way, face-to-face communications used to inform, give demonstrations to, maintain or establish a long term relationship with, or persuade specific members of a particular audience. "(De Pelsmacker, Patrick;Geuens, Maggie; van den Bergh, Joeri, 2007, p464).

"In personal selling, there is direct and personal contact between the sales man and the customer where the customer is informed about the organization and the products and trying to persuade him and raise his desire to own the product, and the sales man gets from the customer information about his views and trends towards the organization and its policy directly and quickly (Said, 1995: 43).

\section{Nature and characteristics of personal selling}

Personal selling is a complex promotional activity. Some define it as: a personal contact process aimed at persuading the prospective buyer to buy a commodity or service that promotes it, and represents a source of material interest to the seller through sales.

Sale of personal has characteristics that distinguish it from the rest of the other promotional activities and most notably the following (Maala, 1996: 369- 370):

1) It represents a direct personal contact process.

2) Instant feedback in it, which coincides with the facts of sales dialogue.

\section{Personal Selling Objectives}

The following are a set of objectives that can be customized for personal sale (Al-Sirafi, 2005: 558- 559): 
1) To search for new customers

2) Get the cooperation of distributors in the storage and promotion of product line.

3) Serve current consumers by contacting them and receiving their orders.

4) Assist in the training of sales men who work for distributors.

5) Provide distributors with advice regarding various administrative problems facing them.

6) Gather the necessary marketing information and submit it to the -management of the organization

7) Maintaining a certain level of sales

8) Obtain and maintain a certain marketing share

9) Maintain the cost of personal selling within certain limits

10) Retain the level of sales in a way that allows to contribute to the goal of profitability

11) Inform customers of changes in the product or aspect of the marketing strategy

12) Complete the sale process as is the case if no promotional mix elements exist

\section{Personal selling steps}

The personal selling process consists of several steps (Al Khatib and Awad, 1420 AH / 2000 AD: 185-118):

1) Identify potential customers

2) Pre-contact: Before contacting potential customers, the salesman must:

a) Learn more about customers.

b) Setting communication goals.

c) Choose the best method of communication

d) Choose the best time to visit; some customers may be busy at certain times

3) Customer contact

4) Display and show product characteristics

5) Address the objections

6) Complete the sale

7) Follow-up

5. Factors influencing the choice of personal selling method

There are a number of factors that influence the choice of personal selling method (Alalag and Rabea'ah, 1998: 71):

1) Number of prospective buyers.

2) The degree of concentration of prospective buyers

3) Order size

4) Product diversity.

5) Lack of homogeneity in customer desires

6) Need to display the product.

7) Buyer resistance.

\section{3/Salesmen}

The seller is the individual who understands all branches of knowledge of the goods he sells, to be sold in a simple, easy way, which helps him to assimilate, and he can reformulate them in different ways depending on the consumers he sells them (Milad, 2003: 273)

The term salesman is used to denote a person who carries out the tasks and sales activities through direct contact with current and prospective customers in order to persuade them to purchase the goods or services. (Bousheriba, 2013: 233)

Salespeople are more than one of the methods companies employ to communicate with their customers.(Shams Aldin,BasimAbdAlRahman 2011, p 4).

\section{Sales men skills and tasks}

The organization can achieve its marketing objectives by possessing competent and well trained personnel. In order to achieve this, individuals must have special characteristics such as competence, possessing the required skill and knowledge, as well as making a mental effort to accommodate the customer and communicate clearly through good listening to the customers, understanding their needs, knowledge of their behavior, the reason for their purchases and providing guidance and advice. If the organization enjoys competent people, its goals can effectively (Alhilo, 2009, $172-173)$.Sales forces must have a number of characteristics to enhance customers' confidence in selling forces, ( Al Helou, 2009, 173)

1) Customer orientation: Here the salesman must definitely go for the benefit of the customer and the benefit of his organization through the balance between the two benefits, with emphasis on non-payment of the product to the buyer if he does not need it.

2) Efficiency: includes what the salesman enjoys of ability and knowledge of the product and a reference to meet customers and how dealing with the product technically with its applications

3) 3-Reliability: It is all about relying on the sales man by his organization to reflect the image of the 
organization through what he performs of his deeds and statements and his high professionalism.

4) Frankness: by the salesman of honesty and sincerity in his speech and his words and situations evidence is used for correct and credible cases

5) Preference: by establishing a strong relationship between the seller and the buyer and through salesmen following the familiar methods depending on the emotional factor and perceived by customers

1. Training and motivating salesmen (Jabr, 2007: 344-346, 348)

1) Sales men training

Training of sales men is one of the main responsibilities of sales management. The department should define several strategies for each of the following topics: The quality of training: The company may decide to train one or more new or other employees or certain groups that need to develop their capabilities ,either to increase their effectiveness in the same job, or in preparation for doing something other than the work they do.

a) Place of training: The training strategy may rely on the company's internal capabilities in training or the use of specialized expertise in this field or both.

b) Training time: Some companies see training as a continuous process for the development of sales men, while some companies resort to them in certain circumstances such as the beginning of recruitment and promotion.

c) Training methods: Sales management depends on one or more of the training methods that can be referred to, such as (lectures, seminars, role representation, case discussion, field training).

2) Stimulus Salesmen:

Salesmen want the incentive system to bring them guaranteed income to feel safe and fair and reward them for the outstanding work they do. In general, the most widely used motivating system can be divided into two main parts:

a) Material Stimulus System

Fixed pay is the simplest way to reward salesmen, as they get fixed amounts for each time period. Some companies rely on commissions mainly to reward sales men.

b) Moral Stimulus system

The sales management uses many methods of moral Stimulus, as well as material one, such as certificates of appreciation, annual leave, and trips for families of sales men, gifts and competitions.

\section{4/Efficiency and effectiveness}

The efficiency of the organization's management reflects the success of this administration in using these available physical and human resources to produce its outputs. The more effective the organization's management, the more efficient it is to achieve the optimal use of the available physical and human resources. Efficiency means reaching targets with improvements in inputs. All components of production are subject to efficiency measurement. It is possible to measure the efficiency of the use of workers, the efficiency of the use of machines, the efficiency of the use of raw materials, and so on. Effectiveness relates to the objectives and results of the organization, therefore efficiency can be defined as the ratio of actual outputs to expected outputs. Effectiveness focuses on the output aspect only of the process and therefore measures the extent to which the organization achieves its objectives and desired outcomes. There are clear and distinct boundaries between efficiency and effectiveness. Efficiency relates to inputs, effectiveness relates to outputs and outcomes. (Jouda, 2014: 227-228)

\section{5/Efficiency control}

Control of marketing efficiency means testing the efficiency of the elements of the marketing strategy, which is the efficiency of sales men, where their efficiency is affected by the rate of requests for daily sales for each man sold and achieved in response to that, and the costs of those requests realized and lost, as well as the number of new customers per vendor. (Bakri, 2012: 396).

\section{The Fourth Topic: Field study procedures}

\section{1/Study tools}

The researchers relied on the questionnaire as the main tool to collect the information of the field study. The questionnaire included a letter to the population of the research, in which, were clarified the subject, purpose of the study, and included two parts:

The first section contains the personal data of the sample of the study, including (gender, age, academic qualification, job title, years of experience, number of training courses in marketing and sales).

The second section consists of (20) questions for each member of the study sample, to determine one answer to any question, according to the five-level Likert scale, which includes five levels (I strongly agree, I agree, to some extent, I disagree, I absolutely disagree). 
Table (1)

Distribution of the questionnaire questions depending on the hypotheses of the study

\begin{tabular}{|c|c|l|}
\hline Question & Number & \multicolumn{1}{c|}{ Hypothesis } \\
\hline Questions from (1-10) & 10 & for the first hypothesis (the first axis: the efficiency of sales men) \\
\hline Questions from (11-20) & 10 & $\begin{array}{l}\text { for the second hypothesis (the second axis: performance factors of sales } \\
\text { men) }\end{array}$ \\
\hline
\end{tabular}

\section{2 / Society and sample of the study}

Is the total group of elements that we seek to summarize the findings related to the problem studied. The study community consists of all individuals belonging to the food companies in Sudan, Morouj Commodities Ltd was taken as a model of the rest of the other food companies focusing on the employees of the company at different levels: (Department managers, unit managers, department heads, district managers, sales supervisors, sales representatives, and employees). The researchers used the stratified sample to include $30 \%$ of the sample. The sample of the study was easily selected for the difficulty of obtaining the study population. The researchers determined the size of the sample in an approximate manner for each group, depending on the size of the society in that group. Table (1) shows the number of questionnaires distributed to the sample, Where the number of members of the study sample distributed (70) questionnaire.

Table (2)

Sample study size

\begin{tabular}{|c|c|c|c|c|}
\hline Number & Group & Distributed & Recovered & Ratio of recovery \\
\hline 1 & Director of Management & 5 & 3 & $60 \%$ \\
\hline 2 & Director of Unit & 5 & 4 & $80 \%$ \\
\hline 3 & Head of Department & 5 & 5 & $100 \%$ \\
\hline 4 & Area Manager & 5 & 3 & $60 \%$ \\
\hline 5 & Sales Supervisor & 10 & 6 & $60 \%$ \\
\hline 6 & Sales Representative & 35 & 24 & $68 \%$ \\
\hline 7 & Other & 5 & 5 & $100 \%$ \\
\hline & Total & 70 & 50 & $71 \%$ \\
\hline
\end{tabular}

Source: Preparation of the two researchers, from the applied study, 2018.

In Table (2) it is clear that the number of recovered respondents was $50(71 \%)$. These numbers are statistically significant, leading to acceptance of the results of the study.

\section{3/stability and truthfulness study tool}

\section{Stability and virtual honesty}

The questionnaires were presented to a number of academic and administrative specialists in order to ascertain the veracity of the questionnaire and the validity of its questions in terms of clarity and drafting. The researchers made the amendments mentioned by some of them or proposed them.

\section{Stability and statistical honesty}

The probabilities of the test lie in that the scale gives the same results if it is used once under the same conditions. The test is completely stable if a test is applied to a sample of individuals, their scores are monitored, and the same test is repeated again on the same group. (Al-far and others, 1996). In order to calculate the accuracy and consistency of the questionnaire, the researchers took a survey sample consisting of ten individuals from the study community. The stability of the questionnaire was calculated from the sample. The result was that the stability coefficient was more than 0.82 , which indicates that the questionnaire is characterized by a high degree of stability and honesty, The purpose of the study makes the results of the census more accurate and acceptable (Alfar and others, 1996).

Table (3)

Stability and statistical honesty

\begin{tabular}{|c|c|}
\hline Karnbach alpha coefficient & number of element \\
\hline $\mathbf{8 1 6}$ & 20 \\
\hline
\end{tabular}

Table (4)

Reliability and statistical accuracy of respondents' responses to the questionnaire

\begin{tabular}{|c|c|c|}
\hline Hypothesis & coefficient of Stability & coefficient of truthfulness \\
\hline First & $77 \%$ & $88 \%$ \\
\hline Second & $76 \%$ & $87 \%$ \\
\hline Full questionnaire & $82 \%$ & $91 \%$ \\
\hline
\end{tabular}

Source: Preparation of Researchers, Applied Study, 2016 
We note that all coefficients of consistency and truthfulness of the sample responses to the questions related to both the hypotheses of the study and the complete questionnaire are greater than $(82 \%)$ indicating that the questionnaire is characterized by a high degree of stability and honesty.

\section{4/Application of the study tool}

The questionnaire was distributed on the sample of the study which numbered (70) questionnaire (as mentioned above), and the size of the retrieved (50) individuals. The data were unloaded in the tables prepared by the researcher for this purpose. The nominal variables were converted (I strongly agree, agree, to some extent, agree or absolutely agree, which is relevant to excellent, very good, good, acceptable,weak, to quantitative variables $(5,4,3,2,1)$, respectively. The researcher prepared the tables and graphs needed for each question in the questionnaire.

The Fifth Topic: the results of the statistical analysis of the characteristics of the study sample

\begin{tabular}{|c|c|c|c|}
\hline \multicolumn{4}{|c|}{ Table (5) } \\
\hline Number & Gender & Number & Ratio \\
\hline 1 & Male & 45 & $90.0 \%$ \\
\hline 2 & Female & 5 & $10 \%$ \\
\hline Total & & 50 & $100 \%$ \\
\hline Number & Age & & \\
\hline 1 & $30-35$ & 30 & $60 \%$ \\
\hline 2 & $36-40$ & 9 & $18 \%$ \\
\hline 3 & $41-50$ & 3 & $6 \%$ \\
\hline 4 & More than 50 & 3 & $6 \%$ \\
\hline Total & & 50 & $100 \%$ \\
\hline Number & Scientific Qualification & & \\
\hline 1 & Middle Diploma & 9 & $18 \%$ \\
\hline 2 & Bachelor & 29 & $58 \%$ \\
\hline 3 & Higher Diploma & 8 & $16 \%$ \\
\hline 4 & Master & 4 & $8 \%$ \\
\hline Total & & 50 & $100 \%$ \\
\hline Number & Job Position & & \\
\hline 1 & Director of Management & 3 & $6.0 \%$ \\
\hline 2 & Unit Director & 4 & $8.0 \%$ \\
\hline 3 & Section Director & 5 & $10.0 \%$ \\
\hline 4 & District Head & 3 & $6.0 \%$ \\
\hline 5 & Sales Supervisor & 6 & $12.0 \%$ \\
\hline 6 & Sales representative & 24 & $48.0 \%$ \\
\hline 7 & Other & 5 & $10.0 \%$ \\
\hline Total & & 50 & $100 \%$ \\
\hline Number & Years of experience & & \\
\hline 1 & less than 5 years & 17 & $34.0 \%$ \\
\hline 2 & $5-10$ years & 24 & $48.0 \%$ \\
\hline 3 & more than 10 years & 9 & $18.0 \%$ \\
\hline Total & & 50 & $100 \%$ \\
\hline Number & $\begin{array}{l}\text { Number of training courses in marketing } \\
\text { and sales }\end{array}$ & & \\
\hline 1 & 5 or less & 32 & $64.0 \%$ \\
\hline 2 & $6-10$ & 15 & $30.0 \%$ \\
\hline 3 & More Than 10 & 3 & $6.0 \%$ \\
\hline Total & & 50 & $100 \%$ \\
\hline
\end{tabular}

Source: Preparation of the two researchers, from the applied study 2018

\section{Gender}

In Table (5) it is clear that the majority of the sample of the study is male (45) by (90\%), while females are (5) by (10\%)

\section{Age}

In Table (5) it is clear that the majority of the sample of the study is among the age group 30-35 years of age (30) by $60 \%$, followed by individuals aged 36-40 years (9) by 18$)$, and individuals less than 30 are (5), (10\%), 41-50, are 
(3), $(6 \%), 50$ and over (3) by (6\%) and (6) \%). This is due to the gender of sample being investigated, and the company exempts those who are over the age of 50 (voluntarily) from focusing on youth.

\section{Scientific qualification}

Table (5) shows that the majority of the sample of the study was a bachelor's degree (29) with a percentage of $(58 \%)$, followed by a middle diploma (9) (18\%), higher diploma (8), (16\%), then individuals with a master's degree $(4 \%)$ by $(8 \%)$ of the surveyed sample, and no other qualifications were shown. It is clear from the above that the bachelor's degree was about (58\%) of the sample of the study, which indicates that the company is interested in the recruitment of qualified individuals, and their answers will support the study, and will contribute to their views to access the results of scientific sound, especially if combined with practical experience, $\mathrm{PhD}$ degree does not exist.

\section{Job Position}

Table (5) shows that the majority of the respondents were sales representative, where they numbered (24) by $(48 \%)$, followed by sales supervisor (6) by $12 \%$, then head of section $(5),(10 \%)$, then other jobs $(5),(10 \%)$, unit director(4) , (8\%), managing director(3), (6\%) and finally district manager(3) $(6 \%)$. In our opinion, the company has a clear diversity in the departments, which indicates that the company keeps abreast of the development of its structure and has become the predominant administrative feature, which is required by the current stage.

\section{Years of experience}

Table (5) shows that the majority of respondents have a long experience of over 5-10 years, where they reached $24 \%$ by $48 \%$, followed by less than 5 years and $17 \%$ by $34 \%$ and more than 10 years. (9\%) by (18\%) of the sample studied. It is clear from the above that the staff of the company accumulated their experience high, in addition to their stability and for their long periods in the company.

\section{Number of training courses}

Table (5) shows that the distribution of the questionnaire to the respondents was based on the training courses for individuals who are directly related to the management of the company and the implementation of its policies. The majority of the sample of the study sample received 5 courses or less(32) by (64\%), followed by those who received courses 6-10 (15) by (30\%)followed by those who received courses more than $10,(3)$ by $(6 \%)$. I could not meet the managers of the companies to fill out the questionnaire on the pretext that the work was stressful, but I did so during the interviews.

The sixth Topic: Results of statistical analysis of the responses of the sample of the study sample on all axes Table (6)

Probable weights for the responses of the study sample members to the study questions

\begin{tabular}{|c|c|c|}
\hline Variable & weight & Probable weight \\
\hline Strongly agree & 1 & $1-1.8$ \\
\hline Agree & 2 & $1.8-2.6$ \\
\hline agree to some extent & 3 & $2.6-3.4$ \\
\hline Disagree & 4 & $3.4-4.2$ \\
\hline Strongly Disagree & 5 & $4.2-5$ \\
\hline
\end{tabular}

Source: Preparation of the two researchers, from the applied study, 2018.

The first axis: Sales efficiency of salesmen

Table (7)

The members of the study approval related to the first hypothesis

\begin{tabular}{|c|l|c|c|c|}
\hline $\mathrm{N}$ & \multicolumn{1}{|c|}{ Phrase } & $\begin{array}{c}\text { Arithmetic } \\
\text { mean }\end{array}$ & $\begin{array}{c}\text { Standard } \\
\text { Deviation }\end{array}$ & $\begin{array}{c}\text { Degree of } \\
\text { acceptance }\end{array}$ \\
\hline 1 & $\begin{array}{l}\text { The educational level of the salesmen in our company } \\
\text { contributes to the success of the sales process. }\end{array}$ & 1.28 & 0.67128 & $\begin{array}{c}\text { Strongly } \\
\text { agree }\end{array}$ \\
\hline 5 & $\begin{array}{l}\text { Salesman in our company has the ability to establish good } \\
\text { relationship with customers }\end{array}$ & 1.28 & 0.45356 & $\begin{array}{c}\text { Strongly } \\
\text { agree }\end{array}$ \\
\hline 6 & $\begin{array}{l}\text { Salesmen in our company have the art of dealing and } \\
\text { speaking to customers }\end{array}$ & 1.48 & 0.50467 & $\begin{array}{c}\text { Strongly } \\
\text { agree }\end{array}$ \\
\hline 8 & $\begin{array}{l}\text { The Salesman in our company explain the commodity in } \\
\text { easy language enables the customer to make his decision to } \\
\text { buy }\end{array}$ & 1.58 & 0.60911 & $\begin{array}{c}\text { Strongly } \\
\text { agree }\end{array}$ \\
\hline 4 & $\begin{array}{l}\text { The salesman in our company has the ability to plan for the } \\
\text { success of the sales process. }\end{array}$ & 1.68 & 0.89077 & $\begin{array}{c}\text { Strongly } \\
\text { agree }\end{array}$ \\
\hline 7 & $\begin{array}{l}\text { The salesman in our company has a degree of intelligence } \\
\text { that enables him to persuade customers to buy }\end{array}$ & 1.7 & 0.67763 & $\begin{array}{c}\text { Strongly } \\
\text { agree }\end{array}$ \\
\hline & \multicolumn{2}{|l}{} \\
\hline
\end{tabular}




\begin{tabular}{|c|l|c|c|c|}
\hline $\mathrm{N}$ & \multicolumn{1}{|c|}{ Phrase } & $\begin{array}{c}\text { Arithmetic } \\
\text { mean }\end{array}$ & $\begin{array}{c}\text { Standard } \\
\text { Deviation }\end{array}$ & $\begin{array}{c}\text { Degree of } \\
\text { acceptance }\end{array}$ \\
\hline 2 & $\begin{array}{l}\text { Salesmen in our company have full knowledge of the } \\
\text { company and its products, enabling them to provide the } \\
\text { customer with the required information to support the } \\
\text { purchasing decision }\end{array}$ & 1.76 & 0.95959 & $\begin{array}{c}\text { Strongly } \\
\text { agree }\end{array}$ \\
\hline 9 & $\begin{array}{l}\text { The salesman in our company has sufficient persuasion skills } \\
\text { to make the sale successful. }\end{array}$ & 1.86 & 0.83324 & Agree \\
\hline 3 & $\begin{array}{l}\text { The salesmen in our company receive continuous training } \\
\text { that increases their ability to contact customers. }\end{array}$ & 2.08 & 0.80407 & Agree \\
\hline 10 & $\begin{array}{l}\text { Salesmen in our company have the ability to take advantage } \\
\text { of customer reaction in improving their work }\end{array}$ & 2.12 & 0.84853 & Agree \\
\hline
\end{tabular}

Source: Preparation of the two researchers, from the applied study, 2018

Table (7) shows that most of the sample of the study:

- strongly agree with the terms (1) (5) (6) (8) (4) (7) (2) shown in the table above, because the values of the arithmetic mean were in the weighted average range (1.8-1) according to fifth Likert scale

- -Agree to the terms (9) (3) (10) shown in the table above, because the values of the arithmetic mean were in the weighted average range $(1.8-2.6)$ according to the fifth Likert scale

Table (8)

Results of the Kay box test to denote the differences of responses to the first hypothesis questions

\begin{tabular}{|c|c|c|c|c|}
\hline $\mathrm{N}$ & Phrase & $\mathrm{Ca} 2$ & $\begin{array}{l}\text { degree of } \\
\text { freedom }\end{array}$ & $\begin{array}{c}\text { Statistical } \\
\text { significance }\end{array}$ \\
\hline 1 & $\begin{array}{l}\text { The educational level of the salesmen in our company } \\
\text { contributes to the success of the sales process. }\end{array}$ & $58.240 \mathrm{a}$ & 2 & .000 \\
\hline 2 & $\begin{array}{l}\text { Salesmen in our company have full knowledge of the } \\
\text { company and its products, enabling them to provide the } \\
\text { customer with the required information to support the } \\
\text { purchasing decision }\end{array}$ & $10.720 \mathrm{a}$ & 2 & .000 \\
\hline 3 & $\begin{array}{l}\text { The salesmen in our company receive continuous training } \\
\text { that increases their ability to contact customers. }\end{array}$ & $.640 \mathrm{a}$ & 2 & .000 \\
\hline 4 & $\begin{array}{l}\text { The salesman in our company has the ability to plan for } \\
\text { the success of the sales process. }\end{array}$ & $29.040 \mathrm{~b}$ & 1 & .000 \\
\hline 5 & $\begin{array}{l}\text { Salesman in our company has the ability to establish good } \\
\text { relationship with customers }\end{array}$ & $9.680 \mathrm{c}$ & 1 & .000 \\
\hline 6 & $\begin{array}{l}\text { Salesmen in our company have the art of dealing and } \\
\text { speaking to customers }\end{array}$ & $.080 \mathrm{a}$ & 2 & .000 \\
\hline 7 & $\begin{array}{l}\text { The salesman in our company has a degree of intelligence } \\
\text { that enables him to persuade customers to buy }\end{array}$ & $10.360 \mathrm{a}$ & 2 & .000 \\
\hline 8 & $\begin{array}{l}\text { The Salesman in our company explain the commodity in } \\
\text { easy language enables the customer to make his decision } \\
\text { to buy }\end{array}$ & $16.840 \mathrm{a}$ & 2 & .000 \\
\hline 9 & $\begin{array}{l}\text { The salesman in our company has sufficient persuasion } \\
\text { skills to make the sale successful. }\end{array}$ & $1.720 \mathrm{~b}$ & 2 & .000 \\
\hline 10 & $\begin{array}{l}\text { Salesmen in our company have the ability to take } \\
\text { advantage of customer reaction in improving their work }\end{array}$ & $1.720 \mathrm{c}$ & 2 & .000 \\
\hline
\end{tabular}

Source: Preparation of the two researchers, from the applied study, 2018.

- Zero hypotheses (there are significant differences between expected frequencies and observed frequencies)

- The alternative hypothesis (there are no significant differences between expected frequencies and observed frequencies)

It is clear from Table (8) that the value of $\mathrm{P}$-Value $(<0.05)$ associated with a Ki statistic is less than 0.05 . Therefore, we can reject the null hypothesis of the $5 \%$ significance level and accept the alternative hypothesis. There are no significant differences between the expected frequencies and the observed frequencies. 
The second axis: factors of evaluating the performance of men of sales among the sample of the study Table (9)

The members of the study sample who agree on the terms and their order according to the degree of approval related to the second hypothesis

\begin{tabular}{|c|c|c|c|c|}
\hline $\mathrm{N}$ & Phrase & $\begin{array}{l}\text { Arithmetic } \\
\text { Mean }\end{array}$ & $\begin{array}{l}\text { Standard } \\
\text { Deviation }\end{array}$ & $\begin{array}{l}\text { Degree of } \\
\text { acceptance }\end{array}$ \\
\hline 7 & $\begin{array}{l}\text { Salesman feeling respectfully towards himself and his abilities } \\
\text { helps his success in his field }\end{array}$ & 1.28 & 0.45356 & $\begin{array}{l}\text { Strongly } \\
\text { agree }\end{array}$ \\
\hline 3 & $\begin{array}{l}\text { Salesmen in our company have selling skills to ensure success in } \\
\text { their work }\end{array}$ & 1.52 & 0.50467 & $\begin{array}{l}\text { Strongly } \\
\text { agree }\end{array}$ \\
\hline 5 & $\begin{array}{l}\text { Confidence of the salesman of our company plays role in the } \\
\text { success of the process of sales }\end{array}$ & 1.62 & 0.6667 & \\
\hline 6 & $\begin{array}{l}\text { Confidence of our salesman with the quality of his products has a } \\
\text { positive impact in his interaction with the buyers' community }\end{array}$ & 1.62 & 0.6667 & $\begin{array}{l}\text { Strongly } \\
\text { agree }\end{array}$ \\
\hline 8 & $\begin{array}{l}\text { The salesmen in our company enjoy a good appearance that } \\
\text { attracts customers to deal with them }\end{array}$ & 1.64 & 0.85141 & $\begin{array}{l}\text { Strongly } \\
\text { agree }\end{array}$ \\
\hline 2 & $\begin{array}{l}\text { Our company is working to stimulate the salesman materially and } \\
\text { morally to achieve the largest possible selling share }\end{array}$ & 1.66 & 0.68839 & $\begin{array}{l}\text { Strongly } \\
\text { agree }\end{array}$ \\
\hline 10 & $\begin{array}{l}\text { The salesman in our company has the ability to convert customer } \\
\text { objections to reasons for buying }\end{array}$ & 1.74 & 0.87622 & $\begin{array}{l}\text { Strongly } \\
\text { agree }\end{array}$ \\
\hline 9 & $\begin{array}{l}\text { The salesman in our company can be patient to try again with the } \\
\text { customer until he earns the sales deal }\end{array}$ & 1.84 & 0.61809 & Agree \\
\hline 1 & $\begin{array}{l}\text { Salesmen in our company functional satisfaction that achieves } \\
\text { effective communication with the buyers' community }\end{array}$ & 1.94 & 0.89008 & Agree \\
\hline 4 & $\begin{array}{l}\text { The salesmen in our company have sufficient experience to } \\
\text { enable them to succeed in their contact with buyers. }\end{array}$ & 1.94 & 0.81841 & Agree \\
\hline
\end{tabular}

Source: Preparation of the two researchers, from the applied study, 2018

Table (9) shows that most of the sample of the study:

- Strongly agree with the terms (7) (3) (5) (6) (8) (2) (10) shown in the table above, because the values of the arithmetic mean were in the weighted average range of (1.8-1) according to the fifth Likert scale

- Agree to the terms (9) (1) (4) shown in the table above, because the values of the arithmetic mean were in the weighted average range (1.8 - 2.6) according to the fifth Likert scale

Table (10)

Results of the Kay box test to denote the differences of responses to the second hypothesis questions

\begin{tabular}{|l|l|l|l|l|}
\hline N & Phrase & Ca 2 & $\begin{array}{l}\text { degree of } \\
\text { freedom }\end{array}$ & $\begin{array}{l}\text { Statistical } \\
\text { significance }\end{array}$ \\
\hline 1 & $\begin{array}{l}\text { Salesmen in our company functional satisfaction that achieves } \\
\text { effective communication with the buyers' community }\end{array}$ & $3.160 \mathrm{a}$ & 2 & .000 \\
\hline 2 & $\begin{array}{l}\text { Our company is working to stimulate the salesman materially and } \\
\text { morally to achieve the largest possible selling share }\end{array}$ & $10.360 \mathrm{a}$ & 2 & .000 \\
\hline 3 & $\begin{array}{l}\text { Salesmen in our company have selling skills to ensure success in } \\
\text { their work }\end{array}$ & $.080 \mathrm{~b}$ & 1 & .000 \\
\hline 4 & $\begin{array}{l}\text { The salesmen in our company have sufficient experience to } \\
\text { enable them to succeed in their contact with buyers. }\end{array}$ & $.280 \mathrm{a}$ & 2 & .000 \\
\hline 5 & $\begin{array}{l}\text { Confidence of the salesman of our company plays role in the } \\
\text { success of the process of sales }\end{array}$ & $12.520 \mathrm{a}$ & 2 & .000 \\
\hline 6 & $\begin{array}{l}\text { Confidence of our salesman with the quality of his products has a } \\
\text { positive impact in his interaction with the buyers' community }\end{array}$ & $12.520 \mathrm{a}$ & 2 & .000 \\
\hline 7 & $\begin{array}{l}\text { Salesman feeling respectfully towards himself and his abilities } \\
\text { helps his success in his field }\end{array}$ & $9.680 \mathrm{a}$ & 1 & .000 \\
\hline 8 & $\begin{array}{l}\text { The salesmen in our company enjoy a good appearance that } \\
\text { attracts customers to deal with them }\end{array}$ & $16.480 \mathrm{~b}$ & 2 & .000 \\
\hline 9 & $\begin{array}{l}\text { The salesman in our company can be patient to try again with the } \\
\text { customer until he earns the sales deal }\end{array}$ & $17.920 \mathrm{a}$ & 2 & \\
\hline 10 & $\begin{array}{l}\text { The salesman in our company has the ability to convert customer } \\
\text { objections to reasons for buying }\end{array}$ & 24.720 & 2 & .000 \\
\hline
\end{tabular}

Source: Preparation of the two researchers, from the applied study, 2018.

- -Zero hypotheses (there are significant differences between expected frequencies and observed frequencies( 
- The alternative hypothesis (there are no significant differences between expected frequencies and observed frequencies)

It is clear from Table (4) that the value of $\mathrm{P}-$ Value $(<0.05)$ associated with a ki statistic is less than 0.05 . Therefore, we can reject the null hypothesis of the $5 \%$ significance level and accept the alternative hypothesis. There are no significant differences between the expected frequencies and the observed frequencies.

\section{The seventh topic: discussing the hypotheses of the study.}

Table (11)

The final results of each axis show the responses of the individuals in the study sample

\begin{tabular}{|l|l|l|l|l|}
\hline & N & Mean & $\begin{array}{l}\text { Std. } \\
\text { Deviation }\end{array}$ & $\begin{array}{l}\text { Degree } \\
\text { acceptance }\end{array}$ \\
\hline First Axis of salesmen's efficiency. & 4 & 1.6820 & .42460 & Strongly agree \\
\hline $\begin{array}{l}\text { The second axis factors of evaluating the performance of } \\
\text { salesmen. }\end{array}$ & 4 & 1.6800 & .40356 & Agree \\
\hline
\end{tabular}

In order to verify the responses of the sample members of the study to approve their results in the community, the Ka 2 test was carried out, as shown in the following table.

Table (12)

Explains Chi-Square Test

\begin{tabular}{|l|c|c|}
\hline & $\begin{array}{l}\text { The first axis is the efficiency of } \\
\text { sales men }\end{array}$ & $\begin{array}{l}\text { Second Axis: Evaluation of } \\
\text { sales men performance }\end{array}$ \\
\hline Chi-Square & $10.800 \mathrm{a}$ & $10.240 \mathrm{~b}$ \\
\hline Degree of freedom & 9 & 5 \\
\hline P- Value & .290 & .069 \\
\hline
\end{tabular}

Source: Preparation of the two researchers, from the applied study, 2018.

- Zero hypotheses (significant differences between expected frequencies and observed frequencies).

- The alternative hypothesis (there are no significant differences between expected frequencies and observed frequencies).

In Table (11) and (12) it is clear that the value of P-Value ( $>0.05)$ associated with the Chi-Square statistic is greater than 0.05 and therefore we can accept the null hypothesis of the $5 \%$ significance level and reject the alternative hypothesis. There are significant differences between expected frequencies and observed frequencies

First Hypothesis:

There is a statistically significant relationship between the sales efficiency variables of the salesmen (education, knowledge, continuous training, skills, ((planning, communication, conversation), intelligence, explain ability of the commodity in easy language, persuasion, recognize the reactions of others) and decision of buyers

In view of Table (7), we find that all the answers of the members of the sample of the study on the terms of the first axis in favor of strongly agree and agree, and since all these words serve the focus of sales efficiency, this means proving the first hypothesis is the existence of a relationship of statistical significance between the variables of sales efficiency of salesmen and purchase decision For buyers.

Second Hypothesis:

There is a statistically significant relationship between variables of evaluation factors Performance of salesmen (job satisfaction, stimulate, sales skills) and effective communication with the buyers' community.

In view of Table (9), we find that all the answers of the members of the sample of the study on the terms of the second axis in favor of strongly agree and agree, and since all these words serve the axis of the factors of evaluating the performance of salesmen, this means proving the second hypothesis is the existence of a statistically significant relationship between variables of evaluation factors Performance of salesmen and effective communication with the buyers' community.

\section{The eighth topic: discussing the results with previous studies}

The first axis: Sales efficiency of salesmen

Question 1: The educational level of the salesmen in our company contributes to the success of the sales process? All members of the study sample agree that the educational level of the salesmen of the salesmen contributes to the success of the sales process.

Question 2: Salesmen in our company have full knowledge of the company and its products, enabling them to provide the customer with the required information to support the purchasing decision?

All members of the study sample agree that the salesmen have full knowledge of the company and its products, enabling them them to provide the customer with the required information to support the purchasing decision. The full knowledge of the company and its products earn the salesman confidence in himself and the possibility of responding to the customer's queries and questions about the company and its products and this would push the 
customer towards the decision to buy.

Question 3: The salesmen in the company receive continuous training that increases their ability to contact customers.

The results of the study agreed with Aisha et al. (2016) that "corporate officials seek to improve the performance of their salesmen by taking care of the sales force management functions of training." This was different from Najahand Nuri study(2016), which says that: "The performance of the institution is weak and the resultant weakness of men's performance is their lack of qualifications. Their recommendations are: to choose individuals who possess the qualities that are primarily based on the knowledge, skills and behaviors of these men, as well as their abilities, Competitiveness, which enables them to achieve creativity and innovation, and all this is done by training and the development of these individuals with motivation and others). "Neven 2010 agrees with the importance of training and says," Train sales representative to pay more attention to customers and try to discover methods and behaviors that make sales representatives more interested in their customers

.As Mahmoud 2003 says: (The need to work on the identification of a sufficient training period in which the sales representatives gets all the information related to the nature of work and the nature of the products that will be marketed). Alsayed and Abdul-Fattah, 1989, recommended designing special training programs for the sellers to guide their behavior towards the customer's attention to a greater degree. These programs should focus on changing the sellers' perceptions and attitudes towards the functionalities and practicing the art of selling the sales and acquiring the skills of dealing with the qualities of the customers.

Question 4: Sales man in our company has the ability to plan for the success of the sales process

The findings of the study agreed with the study of Fatih and Nadia in 2015 were agreed: (The skill of planning affects the performance of the salesman)

In our study we find that all members of the study sample agree that the saleman in the company has the ability to plan for the success of the sales process. The plan is the basis for success. The planning skills of a salesman can enable him to plan well for his sales, earn a sales deal and succeed in his business.

Question 5: Salesman in our company has the ability to establish good relationship with customers All members of the study sample agree that the salesman in the company has the ability to establish a good relationship with customers. Which means their ability to win customers and try to satisfy them, and the formation of a good relationship with the customer will prolong the time in dealing with him and the customer speak well about the company and its products and salesmen.

Question 6: salesmen in our company have the art of dealing and the luxury of talking with customers Alsayed and Abdul-Fattah (1989) states in their recommendations: ((Designing special training programs for sellers These programs focus on changing the concepts of the sellers and their attitudes towards the functional and the practice of the art of dealing with sales and the skills of dealing with the qualities of customers and leading to the application of the modern concept of marketing in the field of sales) ), Which emphasizes the importance of salesman salesmanship with different types of customers so that he can earn as much as possible from the buyers' community and thus increase the selling share. All members of the study sample agree that the salesmen in the company have the art of dealing and the luxury of talking with the customers. This also confirms the company's keenness to train the salesmen in the field of dealing and this is evident more than the number of courses received by the delegate in the field of marketing and selling since joining Company or before

Question 7: The salesman in our company has a degree of intelligence that enables him to convince customers to buy.

All members of the study sample agree that the salesman in the company has a degree of intelligence that enables him to persuade customers to buy.

Question 8: The salesman in our company explains the commodity in easy language that enables the customer to make his purchasing decision

All members of the study sample agree that the salesman in the company explains the commodity in an easy language that enables the customer to make his purchasing decision. Using a salesman for words that are simple and easy to understand and understood by the customer has the positive effect of winning the sale

Question 9: The salesman in our company has enough persuasion skills to make the sale successful

"Mohamed (2013) says that the active role that salesmen play in determining the marketing policy of the organization as the ultimate mediator between them and the customer and their effectiveness to convince them and encourage them to buy," Sayed and Abdul-Fattah 1989:say that customers recognize the sales behavior of sellers as directed to the customer, customer understanding of sales behavior of sellers about vendor recognition of the same behavior for three factors of the study: showing the benefits of the product, honesty in selling persuasion, taking into account the customer's interest. In general, persuasion skills must be highly available to salesmen and enough to convince the customer to buy. All members of the sample agree, but some of them strongly that the sales man in the company has sufficient persuasion skills to make the sale successful

Question 10: Salesmen in our company have the ability to take advantage of customer reaction in improving their work 
All members of the study sample agree that the Salesmen in the company have the ability to take advantage of customer reaction in improving their work.

The second axis: factors of evaluating the performance of salesmen among the sample of the study.

The first question: Salesmen in our company functional satisfaction that achieves effective communication with the buyers' community

All members of the study sample agree that the salesmen in the company have a functional satisfaction that effectively communicates with the buyers'

The second question: Our Company is working to motivate the salesman materially and morally to achieve the largest possible of selling share

The results of the study agreed with the study of Aisha et al. (2016): The officials in the institution seek to improve the performance of their salesmen by paying attention to the functions of selling power management, namely, stimulation, supervision and evaluation. The study recommended the need to provide material incentives to salesmen

The study of Fatih and Nadia in 2015 found that there is an effect on many of the personal traits of the salesman in terms of his performance, in isolation from the rest of the material or moral stimulation. Najah and Nuri 2016, in their recommendations, say: "The choice of individuals who possess the qualities that lie mainly in the possession of these men of different knowledge, skills and behaviors, in addition to having the competitive capabilities that enable them to achieve creativity and innovation, and do that through training and development of these individuals with motivation., Mohammed (2013) says in his recommendations to the institution to pay more attention to the sales force that it owns and the objective selection of salesmen and to develop a motivational system to activate the sales force, as well as to establish scientific and methodological bases to train, stimulate and evaluate the performance of salesmen. Marwan (2001) disagrees ("There is no effective incentive system"). Tarig 1998 says, "Managers should assess the importance of both the negative and positive consequences of selling failures and make informed investment decisions in areas such as training and stimulation." In general, it is clear that incentives have a clear impact on the morale of salesmen and success in their work, and therefore the director's interest in the policies of motivation and consideration at all times and know the impact on the efficiency of salesmen.

The third question: Salesmen in our company have selling skills to ensure success in their work All members of the study sample agree that the salesmen in the company have selling skills to ensure their success in their work. The recommendations of the Najah and Nuri (2016) study: the selection of individuals who possess qualities that lies mainly in the possession of these men for different behavioral knowledge and skills And all that can be used in the sales man and focus on availability during the selection of the salesman - especially the innate skills - because the lack of acquired skills can be addressed through training, and continued training should be continued whenever needed.

Question4: Salesmen in our company have sufficient experience to enable them to succeed in their contact with buyers.

Mahmoud (2003) says: "To use the expertise of qualified representatives in jobs commensurate with their qualifications." As Tarig, 1998, states: (The development of objective criteria to assess the performance of sales staff takes into account the experience of the employee and the nature of the task entrusted to him). Since all the respondents agree that the salesmen in the company have sufficient experience to enable them to succeed in the process of contact with buyers, this means the company's interest in the experience of sales man and focus on them, whether in the selection or the large number of training courses in the same or both because of the experience of success in the work of the delegate, as evidenced by more than a number of training courses in marketing and sales referred to in item (6) table 5. And that the scientific qualification is not enough for the representative, but must be the technical aspect of the sale process, which gained from the accumulation of experience and training. In addition, the company focuses on the experienced people as explained in the explanation of item (5) of table (5). This may be due either to the emphasis on the experience in evaluating the applicants for sales positions or to develop good incentive policies that ensure the survival of the salesman for the greatest possible time in order to benefit from the accumulation of experience and creates loyalty towards the company, or both.

The fifth question: The Confidence of the salesman of our company plays role in the success of the process of sales

The results of the study were agreed with the study of Fatih and Nadia (2015) saying (the effect of psychological and behavioral features such as self-confidence). And provide self-confidence to the salesman push him to win the sale transaction and the customer feels seriously selling man in his speech and removes suspicion and fears of the customer, which prompts the customer to make his decision to buy.

Question 6: The Confidence of our salesman with the quality of his products has a positive impact in his interaction with the buyers' community

all members of the study sample agree that the Confidence of our salesman with the quality of his products has a positive impact in his interaction with the buyers' community. 
Question 7: Salesman feeling respectfully towards himself and his abilities helps his success in his field All members of the study sample agree that a salesman feeling respectfully towards himself and his abilities helps his success in his field

Question 8:. Salesmen in our company enjoy a good appearance that attracts customers to deal with them The results of the study were agreed upon with the study of Fatih and Nadia (2015). Among the findings of the study was: "The customer is influenced by the physical characteristics of the salesman by studying the effect of appearance and its impact on the customer. The good appearance has a positive effect on the customer in dealing with the salesman; he attracts customers to deal with them.

Question 9: The salesman in our company can be patient to try again with the customer until he earns the sales deal

All members of the study sample agree that the salesman in the company patience to repeat the attempt with the customer to win the sale transaction.

Question 10: The salesman in our company has the ability to convert customer objections to reasons for buying. All members of the study sample agree that the salesman in the company has the ability to transfer customer objections to reasons for buying.

\section{The Ninth Topic: Conclusion, recommendations and future visions}

First: Recommendations

The study presented a set of recommendations as follows:

1. Competence and merit in the selection of salesmen in terms of the level of education and knowledge to obtain a more distinctive competencies.

2. Continuing to train and qualify salesmen to achieve a high degree of sales efficiency.

3. The salesman has the ability to plan well for the sales process and to establish a good relationship with the customer

4. The salesman should have a high degree of intelligence, persuasion skills and the art of dealing with customers of all kinds.

5. To have the ability to choose words and phrases that the customer understands in order to make his purchasing decisions.

6. Achieving a high degree of job satisfaction for the salesmen that exceeds the satisfaction of the employees of the competitors.

7. Increasing interest in Stimulation salesmen materially and morally and considering incentive policies from time to time, taking into consideration the incentives received by their counterparts in other similar companies.

8. Provide selling skills to the salesman when chosen.

9. To have confidence in himself and the quality of his products to achieve a degree of success in the sales process.

10. 1Considering the availability of personal qualities and skills when choosing salesmen, especially that cannot be acquired by training.

\section{Second: Future visions}

From the theoretical and practical presentation of this study, a number of topics will be developed which will be useful for future study. Further studies on different samples will be conducted on:

1. The role of the salesmen's efficiency in achieving effective communication with the buyers' community.

2. The role of training in raising the efficiency of salesmen.

3. The impact of the satisfaction of the salesmen on their efficiency in achieving effective marketing communication with the buyers' community.

\section{Acknowledgements}

Thanks to the Morouj Commodities Ltd - Sudan and its staff who agreed to participate in this study. Thanks are also due to Dr. Mohammed Osman and Dr. Mutahar Al-Sayed for their assistances with suggestions and translation.

\section{References}

First: References in Arabic Language:

1. Bashir Abbas Al-Alag, Ali Mohamed Al-Rabaya, Promotion and Advertising, First Edition (Dar Al-Yazuri Scientific Publishing and Distribution, Amman, 1418 AH / 1998).

2. Hanaa Abdel-Halim Said, Advertisement, second edition (the Arab Company for Publishing and Distribution, Cairo, 1995)

3. Mohammed Al-Sirafi, Principles of Marketing - Series of Administrative Knowledge Books - Book II, First Edition (Horus International Foundation for Publishing and Distribution, Alexandria, 2005).

4. Naji Maala, the Scientific Origins of Commercial Promotion and Advertising, Second Edition (Al-Warrag 
Foundation, Amman, 1996)

5. Fahad Salim Al-Khatib, and Mohammed Suleiman Awad, Principles of Marketing / Basic Concepts, First Edition (Dar Al-Fikr for Printing, Publishing and Distribution, Amman, 1420 AH / 2000)

6. Fikri Kabbashi Al-Amin, an Applied Approach in Marketing Management, First Edition (Al-Rashed Library, Riyadh, 2015)

7. How to attract a customer always: the new in the art of selling excellence, Talaat Asaad Abdul Hamid (Library of Shukri, 2003)

8. Ahmed Jabr, Marketing Management - Concepts - Strategies - Application (Modern Library for Publishing and Distribution, Mansoura, 2007).

9. Jafar Abdullah Mousi Idris, Retail and Sales Skills, First Edition (Scientific Khawarizm for Publishing and Distribution, Jeddah, 1434H / 2013G)

10. Mahfouz Ahmed Joudeh, Total Quality Management: Concepts and Applications, 7th Edition (Dar Wael Publishing and Distribution, Amman, 2014)

11. Thamer Yasser Al-Bakri, Marketing Strategies, Arabic Edition (Dar Al-Yazouri Scientific Publishing and Distribution, Amman, 2012)

Second: Periodicals and Scientific Journals

1. Mujahidi, F., and Maddah, N. (2015). The impact of personal characteristics of the salesman on his sales performance: A field study on the automotive sector in Algeria. Journal of the performance of Algerian institutions - University of Qasdi Marbah - Algeria, No.8, 29 - 45. Retrieved from http://search.mandumah.com/Record/705702

2. Aisha, S., Boumedienne, B., and Kheira, G. (2016). Factors Affecting the Performance of Salesmen: A Case Study at Sameha Foundation, Samsung, Wade Arhewa Agency. Al-Hikma Journal for Economic Studies - Al-Hikma Foundation for Publishing and Distribution - Algeria, No. 8; . 274 - 291. Retrieval from http://search.mandumah.com/Record/769720.

3. Aisha, N., and Munir, N. (2016). The Role of Training in the Realization of Sales Skills Development Case Study of TEXALGE Algerian. Journal of the Academy of Social Studies - Algeria, No. 16, 97 - 107. Retrieved from http://search.mandumah.com/Record/769945

4. Boucheriba, M. (2013). Effect of sales force regulation on the organization's marketing performance: Case study of the institution Agricultural machinery AXIUM-SPA. Journal of Human Sciences - Algeria, No. 40, 229 - 243. Retrieved from http://search.mandumah.com/Record/722643.

1. Milad, m. M. (2003). Role of Sales Representative in promotion and marketing of cosmetics: study Field Studies in Curriculum and Teaching Methods - Egypt, No. 91, 264 - 283. Retrieved fromhttp://search.mandumah.com/Record/17177.

2. Naji, A. P., And Sherbini, p. 247 (1989). Sales representative behavior between product orientation and customer orientation: Measuring the perception of buyers and customers in the application of Omar Effendi stores in Greater Cairo. Journal of Finance and Trade. Egypt, Vol. 21, No 247, 3 - 39. Retrieved from http://search.mandumah.com/Record/97179.

3. Hussein, N.A, and Rajab, c. P. (2010). The influence of using sales persons for customer orientation Selling approach on purchase time shortage .. Think \& Creativity - Egypt, Vol. 59, 339 - 355. Retrieved from http: //search.mandumah.com / Record / 155934.

4. Shimoot, m. M. (2001). Difficulties facing insurance sales agents in Jordan. Journal of Jerash For Research and Studies - Jordan, vol. 6, No.1, 133 - 174. Retrieved from http://search.mandumah.com/Record/115966

5. Araafa, i. B. (1998). A field study of the manifestations and causes of selling failure in industrial companies and the results resulting from failure of sales staff. The Scientific Journal of Research and Commercial Studies - Egypt, Vol 12, No..1, 166 - 211. Retrieval from http://search.mandumah.com/Record/69687

Third: References in English Language

1. William M .Pride / 0 .c. Ferrel, Understanding Marketing, Third Edition (Houghton Mifflin Company, London, 1983). Marketing Communications: A European Perspective De Pelsmacker, Patrick; Geuens, Maggie; van den Bergh, Joeri 2007.

2. Communication-in-use: customer-integrated marketing communication Finne, Ake; Gronroos, Christian Vol. 3, No. 51; April 2017, by European Journal of Marketing.

3. Shams Eldin B.A. (2011 ). The Effect of Personal Selling On the Organization Performance: A Case Study of Allianz Group .International Magazine for Commercestudies.No.3, 1-27. Retrieval from http://search.mandumah.com/Record/661765

4. Kakeesh ‘D. F.g ، Al Dmour 'H. H. (2010). The effect of services marketing mix elements on customerbased brand equity: An empirical study on mobile telecommunication service recipients in Jordan (Non published Master Thesis -Jordanian University-Oman. Retrieval from http://search.mandumah.com/Record/555333. 